Of the Causes of Improvement in the productive Powers of Labour, and of the Order according to which its Produce is naturally distributed among the different Rabis of the People

\title{
JOURNAL OF THE HISTORY OF ECONOMIC THOUGHT
}

PUBLISHED FOR THE HISTORY OF ECONOMICS SOCIETY

ihe person holding the sthmical and partly arbitrary, the illustration will the difficulties of some very real and practical problems For indeed the demand and supply schedules do not

v. 1. 1. To represent the equilibrium of demand and supply geometricraw the demand and supply curves together as in Fig. 19. If then the rate at which production is being actually carried on, and $R d$ the 3 greater than $R s$ the supply price, the production 7 profitable, and will be increased. $R$, the amountay call it, will move to the right. On the other less than $R 8, R$ will move to the left. If $R d$ is hat is, if $R$ is vertically under a point of interzurves, demand and supply are in equilibrium. ie taken as the typical diagram for stable equicommodity that obeys the law of diminishing f we had made $S S^{\prime}$ a horizontal straight line, we presented the case of "constent return," in which se is the same for all amounts of the commodity. le $S S^{\prime}$ inclined negatively, but less steeply than asity for this condition will appear more fully later on), we should have stable equilibrium for a commodity which obeys the law of increasing ther case the above reasoning remains unchanged without the alteration letter; but the last case introduces difficulties which wo have arranged may hapt they have and com are not $\mathrm{s}$ met with Of $\mathrm{cc}$ and Nor fluences, of whic] persister them to and No: broader $\S 7$. with in

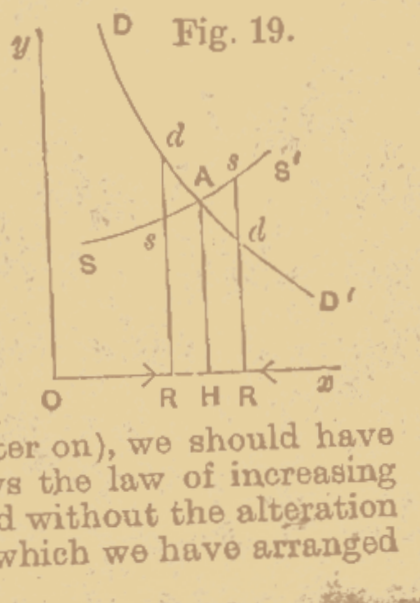




\title{
JOURNAL OF THE HISTORY OF ECONOMIC THOUGHT
}

Journal of the History of Economic Thought (JHET) is the journal of the History of Economics Society. JHET is a quarterly, refereed journal and welcomes papers that reflect the full spectrum of scholarly analysis within the history of economic thought. The Journal also features a regular Book Review section, which includes reviews by leading specialists.

\author{
Editor \\ Stephen Meardon, Bowdoin College \\ Book Review Editor \\ Maria Pia Paganelli, Trinity University

\section{Editorial Board Members}

Michele Alacevich, Loyola University Maryland

Nahid Aslanbegui, Monmouth University

Roger Backhouse, University of Birmingham

Jeff Biddle, Michigan State University

Mauro Boianovsky, Universidade de Brasília

Marcel Boumans, University of Amsterdam and

Erasmus University Rotterdam

Robert W. Dimand, Brock University

Agnès Festré, Université de Picardie Jules Verne

Evelyn Forget, University of Manitoba

Harald Hagemann, Universität Hohenheim

D. Wade Hands, University of Puget Sound

Steven Horwitz, St. Lawrence University
Jimena Hurtado, Universidad de los Andes

Marianne Johnson, University of Wisconsin Oshkosh

Thomas C. Leonard, Princeton University

Harro Maas, University of Utrecht

Steve Medema, University of Colorado Denver

Perry Mehrling, Barnard College, Columbia University

Paul Oslington, Alphacrucis College Sydney and Australian Catholic University

Malcolm Rutherford, University of Victoria

Amos Witztum, London School of Economics and Political Science

Those wishing to submit manuscripts for publication in JHET should do so at the journal's website (http://mc.manuscriptcentral.com/jhet). All manuscripts that pass an initial screening are refereed. Books for review may be addressed to:

\author{
Maria Pia Paganelli \\ Department of Economics \\ Trinity University \\ One Trinity Place \\ San Antonio, TX 78212, USA
}

The HES web page address is http://www.historyofeconomics.org

Annual membership in the History of Economics Society, which includes a one-year subscription to JHET, is $\$ 40$. To become a member of the Society, please visit http://journals.cambridge.org/action/HESHome

Subscription Information: Journal of the History of Economic Thought (ISSN: 1053-8372) is published quarterly, in March, June, September, and December by Cambridge University Press for the History of Economics Society. An annual index and title-page are bound in the December issue. Annual subscription rates for Volume 37 (2015): Institutional subscription rates, print and online: US \$639.00 in the USA, Canada, and Mexico; UK £397.00 + VAT elsewhere. Institutional subscription rates, online only: US \$581.00 in the USA, Canada, and Mexico; UK $£ 361.00$ + VAT elsewhere. Institutional subscription rates, print only: US \$636.00 in the USA, Canada, and Mexico; UK $£ 406.00+$ VAT elsewhere. Individual subscription rates, print only: US \$204.00 in the USA, Canada, and Mexico; UK £119.00 + VAT elsewhere.

Abstract and Indexing Services: Journal of the History of Economic Thought is currently noted in IBZ, IBSS, Economic Literature Database, EBSCO (Business Source Corporate, Business Source Elite, Business Source Premier, TOC Premier), OCLC ArticleFirst Database, OCLC FirstSearch Electronic Collections Online, ABC-CLIO (America: History and Life, Historical Abstracts), Econlit.

All rights reserved. No part of this publication may be reproduced, in any form or by any means, electronic, photocopying, or otherwise, without permission in writing from Cambridge University Press. Permission enquiries from the USA, Mexico, and Canada should be addressed to the New York office of Cambridge University Press, 32 Avenue of the Americas, NY, NY 10013-2473 http://www.cambridge.org/us/information/ rights/contacts/newyork.htm; permission enquiries from elsewhere should be addressed to the Cambridge office http://www.cambridge.org/uk/information/rights/contacts/cambridge.htm; permission enquiries from Australia and New Zealand should be addressed to the Melbourne office http://www.cambridge.org/aus/ information/contacts_melbourne.htm.

Photocopying Information (for users in the U.S.A.): Notwithstanding the above, the Item-Fee Code for this publication (0067-2378/15) indicates that copying for internal or personal use beyond that permitted by Sec. 107 or 108 of the U.S. Copyright Law is authorized for users duly registered with the Copyright Clearance Center (CCC), provided that the appropriate remittance is paid directly to: CCC, 222 Rosewood Drive, Danvers, MA 01923 U.S.A. Specific written permission must be obtained for all other copying; contact the nearest Cambridge University Press office.

Periodical postage paid at Jamaica, NY and additional mailing offices. Postmaster: send addresses to Journal of the History of Economic Thought, Cambridge University Press, 100 Brook Hill Drive, West Nyack, NY 10994-2133. 


\section{JOURNAL OF THE HISTORY OF ECONOMIC THOUGHT}

Volume 37

Number 3

September 2015

\section{Articles}

Two Unpublished Letters by David Ricardo on a Monetary Pamphlet by Samuel Tertius Galton

Christophe Depoortère

Isaak Rubin: Historian of Economic Thought during the Stalinization of Social Sciences in Soviet Russia

Ivan Boldyrev and Martin Kragh

Harvard Meets the Crisis: The Monetary Theory and Policy of Lauchlin B. Currie, Jacob Viner, John H. Williams, and Harry D. White

Michele Alacevich, Pier Francesco Asso, and Sebastiano Nerozzi

Fixed Capital in Agriculture: Richard Jones's Critique of Ricardo's

Theory of Rent

Christian Gehrke

The Origin of the Sylos Postulate: Modigliani's and Sylos Labini's Contributions to Oligopoly Theory

Antonella Rancan

On the Concept of 'Felicitas Publica' in Eighteenth-century

Political Economy

Federico D'Onofrio

\section{Book Reviews}

Paul Cheney, Revolutionary Commerce: Globalization and the

French Monarchy

Loïc Charles

David Simpson, The Rediscovery of Classical Economics:

Adaptation, Complexity and Growth

Frederic Sautet

Angeliki E. Laiou, Economic Thought and Economic Life in Byzantium Christos P. Baloglou

Geoff Pilling, Marxist Political Economy. Essays in Retrieval:

Selected Works of Geoff Pilling

Michael Perelman 
Evert Schoorl, Jean-Baptiste Say: Revolutionary, Entrepreneur,

Economist

Evelyn L. Forget

Christopher J. Berry, The Idea of Commercial Society in the Scottish Enlightenment

Leonidas Montes

Wayne A. Leighton and Edward J. Lopez, Madmen, Intellectuals, and Academic Scribblers: The Economic Engine of Political Change Shruti Rajagopalan

Ryuzo Kuroki, ed., Keynes and Modern Economics

Sylvie Rivot

Geoff Harcourt and Peter Kriesler, eds., The Oxford Handbook of Post-Keynesian Economics

M. G. Hayes

Christos P. Baloglou, Aristotle and the Economic Science:

A Historical and Economical Miscellany

Denis Drosos

Samuel Hollander, Essays on Classical and Marxian Political Economy: Collected Essays IV

A. M. C. Waterman 